\title{
A Critical Analysis of the Sonnets by two Ndebele Poets; Simon J. Nondo and Joseph N. T Dupute
}

LillieBeth Hadebe $(\mathrm{PhD})$

Senior Lecturer, Zimbabwe Open University, Alpes Rd, Harare, Zimbabwe

DOI: $10.36348 /$ sijll.2020.v03i02.002 | Received: 20.01.2020 | Accepted: 27.01.2020 | Published: 27.02 .2020

*Corresponding author: LillieBeth Hadebe

\section{Abstract}

The paper sought to make an analysis of Ndebele sonnets by Simon J. Nondo and Joseph N.T. Dupute. Before a detailed study of the sonnets is made, a discussion of the nature of poetry and the various poetic genres is done. This discussion is intended to show the place of sonnets within the wider field of poetry. Fourteen sonnets are analysed in respect of their form, themes and language. Of these six were written by Nondo and eight by Dupute. The analysis revealed that African writers have borrowed the sonnet forms from the western world. The Petrarchan, Spenserian, Shakespearean and Miltonic rhyme schemes might not have been possibly used in the Ndebele sonnets studied but alliterative concords and stylistic devices are used in the sonnets to enrich the sonnets and create a unique style.

Keywords: Poetry, sonnet, stylistic devices.

Copyright @ 2020: This is an open-access article distributed under the terms of the Creative Commons Attribution license which permits unrestricted use, distribution, and reproduction in any medium for non-commercial use (NonCommercial, or CC-BY-NC) provided the original author and source are credited.

\section{INTRODUCTION}

This is a critical analysis of the sonnets of two Ndebele poets, Simon J. Nondo and Joseph N.T. Dupute. The sonnets to be studied are:

\section{S. J. Nondo:}

\author{
Amabhawa \\ Ingoma Yesalukazi \\ Lapha Ngicabanga \\ Mpande ye- Afrika \\ IEyidzi \\ Lub'elihle Lami
}

$\begin{array}{ll}\text { J. N. Dupute: } & \text { Ikhwibi } \\ & \text { Ngivumele Nomazilo } \\ & \text { Woza Fresh } \\ & \text { Inyonyana Yamanzi } \\ & \text { Inkanku } \\ & \text { Ngitshele Dlamedlu } \\ & \text { Vuka Mlambatha } \\ & \text { Ngo Bulawayo }\end{array}$

It is hoped that the information provided about sonnets, in this study, will broaden both the teacher's and the student's knowledge of Ndebele poetry in general and Ndebele sonnets in particular. It is also hoped that an understanding of sonnets will not only serve to inform the reader about this poetic genre but will also serve to inspire aspiring sonneteers to write their own poems. Sonnets, as a poetic form, belong to the wide field of poetry. Before the sonnets are studied in detail the writer will briefly discuss the nature of poetry and the main poetic genres.

\section{Poetry in General}

Many writers have tried to define poetry. In the process of defining poetry, the aims of poetry have been described and the character of poets has been revealed. Shelley, in Simpson [1] says:

"Poetry is the record of best and happiest moments of the happiest and best minds.... Poetry turns all things to loveliness, it exalts the beauty of that which is most beautiful, and it adds beauty to that which is most deformed...."

Adam, in Alan [1] observes that, "Poetry is rhythmic language charged to the highest possible degree with thought and feeling". In poetry, words and lines are put together in pleasurable correspondence each time developing the central idea of the poem. Shelley thus likens a poet to a nightingale. The poet, like a nightingale sings sweet sounds to cheer the lonely and the solitude. The poet's experiences, be they imaginative, emotional or intellectual are expressed in a language which is compressed, intense and figurative. Language is used in such a way that it creates pictures and experiences in the mind of the reader or listener. Burton, therefore, sees poetry as demanding a highly 
imaginative use of language if the reader's feelings are to be aroused. He feels that the words that are in poetry should have that 'imagination stirring' quality in them.

Poetry is also characterized by rhythm and rhyme. Burton (1974: 36) states that, "Rhythm is a fundamental phenomenon in life, and it is poetry's dependence upon it that helps to make poetry so powerful an influence in the lives of men". The regular rhythm that exists in poetry gives poetry some musical characteristics. Music has these recurring patterns of rhythm which stir up the reader's deeper feelings. Rhythm comes by through sound and it is sound that gives poetry its form. Therefore, poetry should be read aloud if the reader is to gain that natural rhythmic satisfaction needed by all human beings.

Poetry can be divided into two wide classes: the hedonistic and the didactic. Whilst some people believe that poetry should be solely for pleasure others believe that poetry should instruct, teach and moralize. When writing about Wordsworth, Winkler, in Ford [3], notes that; "Wordsworth has in some sense a lesson to teach us.... Didactism did not of course enter poetry with Wordswoth". This is because Wordsworth was one of those poets who felt that their duty as poets was to teach and moralize their readers. However, Somerset Maughan, in Burton [4], bluntly says, "Art is for delight". People like Roscommon, in Simpson [1] believe that "a poet should instruct, or please or both".

Poetry, just like any other work of art, comes out naturally. Studies by Ford show that poetry has its origins in the impulse to tell how one feels. After experiencing a spontaneous overflow of feelings, the poet sits down to write his poem. John Keats in Ford [3] thus states that; "If poetry comes not as naturally as the leaves to a tree it had better not come at all".

All nations have their own poetry. This statement applies to the nations of Africa too. Poetry in Africa is, probably, as old as people of this continent. People have always appreciated beauty. Verses have always been composed as people observe life and nature. Ceremonies of birth, initiation, marriage, wedding, death and burial were accompanied by rhymes, choruses, lyrics and dirges. Praise poems, love songs and lullabies have always existed. Mezu, in Killam [5] thus describes African poetry as, "a common heritage shared by all and handed over from generation to generation". However, African poetry has mainly existed in oral forms. A few examples have been recorded over the years. However, most of these recordings have been done by outsiders who have seen them through their own eyes.

African poets like, Vilakazi, among the Zulu, Mqhayi among the Xhosa, N.S Sigogo among the Ndebele and Solomon Mutswairo among the Shona have tried to carry forward the original African forms.
However, most of these African pots have read Milton, Shakespeare, Spenser, Keats, Wordsworth and other great poets from the Western world. Thus, although African poets still express pride in, and a love of African heritage, the structure and forms of Western poetry have permeated African poetry. Epics, satire and lyrics of all forms have been produced in Africa. This includes Zimbabwe. S.J Nondo has produced praise poems, epics, sonnets and ordinary poems in Ndebele. Studies by Collin and Style [6], show that Shona poets, like Solomon Mutswairo, Herbert Chitepo and Wilson Chivaura, have written lyrics mainly in Shona. The famous Shona epic is "Soko Risina Musoro" by Herbert Chitepo.

Now that poetry has been briefly discussed, the writer will proceed to indicate what some of the main poetic genres are.

\section{Epic Poetry}

Studies by Thomson [7], Simpson [1], and Benton [8] show that an epic is a long, narrative, heroic poem written in one long verse. It has its origins deep in the pre- historic stories of gods and supernatural beings. The epic poem recounts heroic actions of usually, one principal hero. This hero is invested with qualities far superior to those of simple human beings. The fate of the hero and the fate of the nation are the concern of the gods. In epics gods mingle with men and thus heavens intervene in the hero's or nation's affairs.

Since epic poetry deals with heroes of national significance and gods, it, therefore, uses special language. Nondo [9] observes that:

"The language of epic poetry is lofty and heroic. It is full of imagery. Speeches abound in the narrative. These can be passionate, fiery, forceful and direct".

Language used in epic poetry is, therefore, consciously superior, heroic, and grand and dignified making the whole poem highly elevated. Some of the main epic types are the Homeric epic, "The Iliad", which is a complete story of the Trojan War and the Roman epic, "The Aeneid" of Vergil which narrates the escape of Aeneas with his father, son and followers from burning Troy. There is also Milton's English epic, "Paradise Lost", whose incidents take place in heaven, Hell and Earth. This epic is about the fall of man. The Zulu/Ndebele praise poems have been considered to have features of epics. Thus, when writing about Zulu praise poems, Cope [10] notes that; "As an epic the praise poem gives an account of the chief's actions and an account of his reign". S. J Nondo, a Ndebele poet, has written an epic which traces the Ndebele people from Zululand to the present Zimbabwe. The epic is entitled "Ukwakhiwa kwesizwe". As mentioned earlier, the Shona epic is "Soko Risina Musoro", by Herbert Chitepo. 


\section{The Satire}

Petro [11] defines a satire as; "a poem in which wickedness or folly is censored". In a satire there is a display of downward disapproval. A variety of literary and rhetoric devices are used to plainly expose the folly. Studies by Petro, Wolfe and Sutherland show that an art of persuasion is required in a satire. The satirist's aim is to persuade the reader to admire or despise, to look beneath the surface of things, to change sides in politics or region, to return to or to abandon the old and to face ugly facts. His aim is, surely, to persuade the reader or the listener to agree with him and thus laugh at the absurdities exposed. To accomplish this, the satirist, thus employs sarcasm, irony, mockery parody and understatements. Although the satirist presents himself as a mild and honest person, he uses just anything to make the object of attack detestable abhorrent and ridiculous. It should be noted that these targets of satire are not all fictitious. They should be obvious to the reader. Wolfe [12] thus says; "The reader should be able to point out the individual, group, institution, custom, belief or idea which is under attack".

According to R.C.E in the New Encyclopedia Britannica, a satire has two uneven parts. The first part is called the thesis. In this part, vice or folly is examined from many different angles. The second part is called the antithesis. In the antithesis, an opposing virtue is recommended. Thus in a satire, amid all the confusion of sarcasms, irony and all that is used to expose the folly, a call towards order exists.

Satires can be fatal. History has it that in the seventh century, a poet Archilechus satirized his prospective father-in-law Lycambes. Lycambes and his daughter both hanged themselves out of shame. However, it should be noted that though satire is invective, it is also humorous.

Roman poet like Horace, Juvenol, Persius and Lucilius are some of the known satire writers. Due to their influence, satire may thus be Horatian or Juvenalian. English poets like Donne, Johnson, Alexander Pope, John Dryden and Lord Byron have written satires. Donnie's "Satire IV" is Horation and Johnson's "Vanity of Human Wishes" is modeled on Juvenal. Alexander pope, whose master was John Dryden, wrote satires like, "Imitation" and "An Epistle to Dr Arbuthnot". Lord Byron is known for his satire "The Vision of Judgment". In Ndebele, the poem, "Ubuso Mamazala Sobuyimihwabha" by S.J Nondo, satires an old lady who tries to appear as young as a girl through extensive use of cosmetics.

\section{Drama}

Drama, as a poetic genre, includes masque. This is a type of dramatic composition by amateur artists. It was popular in England between the sixteenth and seventeenth centuries. It is mainly meant to entertain. Drama also includes a ceremonial form of prayer consisting of a series of invocations and responses called litany. An example of a litany is the "Anglican Book of Common Prayer".

Drama also includes the dramatic monologue. This is a speech by a single person without other actors taking part in the conversation. Simpson [13] gives, "My Last Duchess", by Robert Browning and "The Love Song of J Alfred Prufrock" by T.S, Elliot as examples of dramatic monologue.

In drama, dramatic monologue comes mainly, in the form of dramatic soliloquy. The actor talks to himself, usually oblivious of his audience, thus revealing his innermost thoughts and feelings.

Drama may also be written in prose. This type of drama has all the qualities of a poem with one exception. It is not written in lines of verses like poetry. It is written in prose. Traditional storytelling and masquerades are examples of drama in the African society. In storytelling, folktale narration in particular, the story teller or performer tries by all means to portray each character in turn. The performer achieves this through extensive use of body movements and voice modulation.

\section{Lyric Poetry}

According to Matthew Black, in Halsey [14], lyric poetry, broadly, includes any form of poetry which is intended to be sung. Lyric is a Greek word which means a kind of poetry spoken or sung to the music of the lyre. A lyre is an ancient plucked string instrument. It consists of a sound box with two symmetrical arms supporting a cross piece from which strings are stretched over to a bridge where they are tuned by means of twisted thongs or pegs.

Lyric poetry is usually brief. Deeply felt emotions are expressed, usually on impulse, in high sounding language. Meanings of words are extended. Rhythm and rhyme are a necessity so as to give the poem song-like characteristics. The lyric genre has a number of special forms, some of which are listed below.

\section{The Ballad}

Studies by Hodgart [15] show that this form of lyric poetry is derived from the Latin word "ballare" which mean, 'to dance'. Ballad has developed and transformed over the years to include the Italian ballad which is a lyric poem with an elaborately rhymed stanza and the French ballad of the fourteenth and fifteenth centuries. The French ballad had one particular and complex verse form with rhymes ababbcbc. The last line is a refrain. 
Today's ballad is a narrative form. It was taken to England in the sixteenth century and it was, mainly, used for political and social verses. The English ballad includes the traditional Anglo- Scottish song called Country Ballads and the Town Ballads. According to Hodgart [15] Town Ballads,

"Described marvelous event...., voiced complaints against social abuses, sang in fact everything likely to interest the public".

Town Ballads include "A Ballade of the Scottyche Kynge" by John Skelton, and "King John Abbot of Cantebury". Like all other lyric poetry, the language of ballads is compact and condensed. The ballad is presented, mainly in dialogue. In Mpofu [16] the poem "Isililo Somkhobo", probably displays the characteristics of a modern ballad. "Isililo Somkhobo" is a narrative poem expressing feelings of a man who has been gradually transformed into a wizard's familiar.

\section{The Ode}

Edmund Gosse, in Jump [17], defines the ode as:

"Any strain of enthusiastic and exalted lyrical verse, directed to a fixed purpose and dealing progressively with one dignified theme".

An ode is basically a song for a public occasion. It usually expresses the feelings of a group. In the fifth century, Pidar wrote an ode in honour of the winners of the Olympic Games. Pindaric ode was so constructed as to have nine stanzas divided into three groups; the strophe, the antistrophe and the epode. According to Simpson, the strophe was sung whilst dancing to the left, the antistrophe whilst retracing the pattern to the right and the epode whilst standing still. The epode is metrically different from the strophe and the antistrophe. Pindar and Horace remain the two dominant figures in odes. Odes are, therefore, Horation and Pindaric.

Although an ode is meant to be sung, it has a serious tone. The language is serious and dignified; it is also highly descriptive and richly concentrated in expression. English ode writers include poets like, Percy Bysshe Shelley who wrote the "Ode To The West Wind" and "Ode To The Skylark". John Keats wrote "Ode To Psyche", "Ode To A Nightingale", "Ode To Autumn", "On a Grecian Urn" and many others. According to Mootry, in Jones [18], Vilakazi's poetry has three titles influenced by Keats and Shelley. These are "Ukhamba luka Somkomose" (Somkomose's Bowl), "Inqomfi" (The Lark) and "We Moya" (Hail Wind). They were modeled on Keats, "Ode To The Grecian Urn" and Shelley's "Ode To The Skylark" and "Ode To The West Wind", respectively. The Zulu/ Ndebele praise poems have also been considered to have features of odes. Cope [10] thus asserts:

"As an ode the praise poem gives an account of the chief's personality".

\section{The Elegy}

According to Simpson [13], the word elegy was, "derived from the Greek, E E legein! To cry woe, woe!"

Although to the Greeks, the elegy was a metrical form for love poetry, to the Romans an elegy meant a poem written in elegiac couplets. Studies by Thomson show that an elegiac couplet was simply a pair of lines with the first line having a dactylic hexameter and the second line having a dactylic pentameter. Ovid, a great Roman poet, wrote the elegy, "The Amores". This elegy was translated into English by Marlowe, who entitled it "The Elegies of Ovid". Donne then wrote "Elegies", probably, after reading Marlowe's "Amores".

Today's elegy is applied to a verse that expresses sorrow over the dead. This elegy is usually divided into three parts. The first part is a lament, then there is a question or complaint and finally there is a philosophical solution. Many English poets have since written elegies. These poets include Waller, Dryden, Donne, Pope and Ben Johnson. The most famous English elegy is, probably "Elegy written in a Country Churchyard", by Thomas Gray. Traditionally in Africa, on the death of a renowned villager, chief, king or distinguished politician, verses are created to mourn the dead. Poetry books published in Zimbabwe, after the country's liberation war, have elegies to express sorrow and grief for those lost during the struggle.

\section{The Sonnet}

A sonnet Is probably the best known of all the set forms of the lyric genre. It is the main subject of this study and, therefore, it will be studied in greater detail. According to Nye [19].

"The word sonnet comes from the Italian sonnet, meaning a little sound or song".

The sonnet was given character as well as form by the Italian poets of the Renaissance. It was then imported into England by Sir Thomas Wyatt when he came back from a diplomatic mission in 1527 .

Early sonnets were mainly of courtly love by yearning suitors and dejected lovers. It was not until poets like, Milton, Donne and Wordsworth began writing sonnets that it was fully discovered that sonnets could venture into other fields. Donne's 'holy' sonnets are addressed to God. Milton's sonnets are addressed to friends and to important people like Oliver Cromwell, a British general. Although a wide range of topics have been accommodated since the introduction of sonnets into England, Crosland [20] feels that the subject matter of sonnets has its degrees of suitability. On the same note is Richmond [21] who feels that sonnets are best suited for themes that are serious and dignified? However, this does not mean that sonnets have to be solemn and grave affairs. It is because of such subject 
matter that Wells [22] feels that sonnets are not for continuous narration. Wells feels that sonnets require crystallization of thought around points of emotion, passion, meditation and remembrance.

The subject matter of sonnets has changed over the years but, still the sonnets have maintained their form. A sonnet is well known for its form of fourteen lines. In writing a sonnet, the sonneteer either increases or fuses the matter to fit the fourteen lines. However, studies by Hubler [23] shows that sonneteers like Shakespeare had great conviction that matter should take precedence over form. It is on this note that Shakespeare, at times, though on very few occasions, had sonnets with twelve or fifteen lines.

Poetry, generally, uses a language of imagination. The diction of sonnets has its own characteristics. The words used create the impression of richness. Although the words may be simple, they are used in an imaginative way so as to give them extended and heightened meaning. Being so short, a sonnet packs a lot of meaning into a single word. Each line carries only the essential fact and each line contributes to the development of the theme of the sonnet. Extending the meanings of words in a meaningful way stimulates and delights the reader's imagination causing the reader to think doubly. Richmond [21] thus says:

"Being short, many sonnets give the impression of being highly condensed: they compress thought and emotion into a few lines, often in language so closely- knit that the full value of the words tends to be overlooked at a first reading".

Studies by Simpson [13], Richmond [21], Moody [24] and Chatwin [25] show that imagery is particularly, important to the sonnet. This is because; in a sonnet a poet has to create an impression of vastness in a few words.

Generally, images are introduced in poetry to evoke the reader's imagination. Imagery appeals to the sense of sight and the sense of imagination. Metaphors and similes are used to give clear mental images. A simile compares two objects by showing similarities in some of their attributes. A metaphor omits 'as' and 'like' and makes one thing another. In sonnets both simile and metaphor may be used in extended forms to bring out the main thought. Shakespeare once wrote:

"That time of the year thou may'st in me behold

When yellow leaves, or none, of few, do hang Upon these boughs which shake against the cold,

Bare, ruin'd choir, where late the sweet birds sing".
In this excerpt, Shakespeare, figuratively, compares his life to autumn, a season between summer and winter. A metaphor has been extended and successfully used to bring out the main thought in this quatrain.

There is a lot of word play in sonnets. It is this word play which gives the sonnet its sound and sound is very important in sonnets. Sound makes the sonnet appeal to the mind as well as to the ear. It should be noted that a sonnet, as a form of lyric poetry, still maintains its singing line. Like any form of lyric poetry, a sonnet, therefore, deserves to be read aloud since a lot of meaning lies in the sound of the words. In sonnets, alliteration is combined beautifully with assonance to give the sonnet song like characteristics. Both alliteration and assonance lead to rhythm. A verse full of rhythm is pleasurable to the ear and facilitates retention. Physical processes like breathing, eating, succession of day and night or the months and seasons occur repeatedly and rhythmically in our daily lives. Moody [24] thus says;

'An appreciation of rhythm is embedded deeply in human consciousness'

Sonnets are, however, best known for their rhyme. Sonnets are, particularly, known for their end or terminal rhyme. Moody [24] describes rhyme as repetition of similar sounds in word endings. This repetition of sounds is patterned so as to give a definite rhyme scheme. Elizabeth Barret Browning in her sonnet, 'If Thou Must Love Me', writes;

'If thou must love me, let it be for nought

Except for love's sake only. Do not say

I love her for her smile-her-look-her way

Of speaking gently, - for a trick of thought'.

The word 'nought' rhymes with 'thought' and 'say' rhymes with 'way' thus giving a definite rhyme scheme; ABBA. However, it is important to note the effect which rhyme has. Rodway [26] says:

'Rhyme helps to set a piece of writing apart as clearly as object for contemplation, to bind a poem together even though it may lack an argument, to emphasize thrust and parry in the content,.... Or to satisfy the primitive delight in similar sounds evidenced by small children's nonsense rhyming.'

As we can see, it is rhyme that cements the whole theme in a sonnet. Rhyme connects words and ideas together. As seen in studies by Rodway, the ear naturally expects a certain prescribed sequence of rhymes. Rhyme, therefore, provides gratification of this created expectation. A rhyming verse is thus pleasurable to the ear and its appeal goes through the ear direct to the reader's emotions. It should, however, be noted that rhyme is most satisfying when it is not only decorative but meaningful. 
Great sonneteers like, Francesco Petrarca, William Shakespeare, John Milton and Edmund Spenser have each followed the sonnet form of fourteen lines with each introducing his own rhyme scheme. All the rhyme schemes involve repetition of identical or of related sounds at the end of each line. It is because of these rhyme schemes that, when studying sonnets, we commonly speak of the Petrarchan sonnet, the Spenserian sonnet, the Shakespearean sonnet and the Miltonic sonnet. Each sonnet type is distinguished by its rhyme scheme as shown below, through studies by Richmond [21], Nye [19], Hubler [23] and Wells [22].

\section{The Petrarchan Sonnet}

The Petrarchan sonnet is divided into two parts. The first eight lines are called the octave. They rhyme ABBAABBA. The remaining six lines are called the sestet. These lines rhyme CDECDE or CDCDCD. There may be variations in the sestet rhyme, but a true Petrarchan sonnet will never allow more than a total of five rhymes.

In the Petrarchan sonnet the pause or volta is clearly marked. There is a marked shift of emphasis in thought. The octave puts forward the theme or the problem to be examined and the sestet comes in with a resolution.

\section{The Spenserian Sonnet}

The Spenserian sonnet has fourteen lines rhyming ABABBCBCCDCDEE. This type of sonnet by Edmund Spenser is also known as the link sonnet. This is because there is no break or turn between the octave and the sestet of a Spenserian sonnet. The final couplet EE is epigrammatic. The statement is usually short and amusing. This final couplet, 'EE', is an English innovation.

\section{The Shakespearean Sonnet}

The Shakespearean sonnet fourteen lines divided into three quatrains and a binding couplet. The first quatrain discloses a reaction to a trying situation and the second comments on that reaction. As shown in studies by Rodway [26], the third quatrain finds some justification for the reaction and the couplet sums up the complicated position. There is a pause after each quatrain and the greatest pause comes after the third quatrain.

The Shakespearean sonnet allows a variation of seven rhymes. The rhyme scheme is, ABAB CDCD EFEF GG or ABBA CDDC EFFE GG. The Shakespearean sonnet has been so widely used that it has come to be known as The English Sonnet.

\section{The Miltonic Sonnet}

The Miltonic sonnet has fourteen lines. It strictly retains the octave of the Petrarchan sonnet, ABBAABBA. THE Miltonic sonnet, however, has no pause or change of direction at the beginning of the sestet. This lack of a pause or volta between the octave and the sestet has made it difficult for other people to imitate Milton although few poets have been able to imitate him with success. The rhyme scheme for the sestet is CDECDE.

Since the introduction of the mentioned rhyme schemes by these given sonneteers, many modern poets tend to follow the provided rhyme schemes when they are writing sonnets. Nye [19] says:

'It is only fair to add that the sonnet is not a piece of poetic mathematics but a form of poetic freedom'.

Although all sonnets may have fourteen lines, no two sonnets will ever be the same as each sonneteer uses his/her own word play. It is in this light that writers, like Hubler, feel that poetry writing is only for those people who have interest in words and word patterns. Through word play, the sonnet lines are crystallized to fourteen lines. Crystallized in this way, a sonnet, therefore, forces the reader to employ all his wit if he is to interpret the sonnet before him. The reader will not only interpret the sonnet but the reader's ear and heart will retain and remember, pleasurably, all the rhyming sounds in the read sonnet.

Now that sonnets have been briefly described, the writer will now proceed to examine sonnets by two Ndebele poets, Simon J. Nondo and Joseph N.T Dupute.

\section{Critical Analysis of Simon J. Nondo and Joseph N.T Dupute Sonnets}

Although Simon J. Nondo and Joseph N.T Dupute have written their sonnets in Ndebele, one might still ask the following question: How far have Nondo and Dupute borrowed from Milton, Spenser, Shakespeare and/or Petrarch? It should, thus, be noted that, although, lyric poetry has always existed in traditional Africa, the sonnet, as a special form of lyric poetry, is something new in Africa. In traditional Africa, lyrics were sung during ceremonies commemorating the birth of children. Lyrics were also sung in wedding ceremonies and on some other joyous occasions. Poetry composition, in general and lyric composition, in particular, was a collective experience. A little poem composed by an individual in one village would grow longer or shorter as it rolled from one village to another. It was thus difficult to control the length of poems. Owing to the absence of a sonnet, as a special form of lyric poetry, in Africa, it, therefore, becomes necessary for African sonneteers to adopt the sonnet form of other nations. The Ndebele sonnets by Nondo and Dupute are thus based on the well known forms and structure of some English sonnets.

The fourteen sonnets studied, all have fourteen lines each. There is a notable change of thought within all the sonnets. The subject is introduced in the first 
lines and a notable shift of thought or a change of mood occurs in the last lines, usually bringing in a resolution to the problem introduced. However, matter seems to take precedence over form where this change of thought is concerned. Both poets have no definite place for a pause or volta in their sonnets. A change of thought comes after seven, nine or ten lines and on some occasions after the prescribed eight lines.

In the sonnet, 'IEyidzi' Nondo exposes Danisile's degenerating facial features in the first eight lines. In the sestet, the poet concentrates on Danisile's chest and stomach. In the sonnet, 'Ikhwibi' the first nine lines are a description of the birds' movement to the east as seen in the first line of the sonnet:

'Mbo kanyekany' empumalanga'

Translation:

All at once to the east was overcast.

A change of thoughts occurs when the birds change direction and fly to the west. To introduce the thought in the last five lines, Dupute writes:

'Mbo kanyekany' entshonalanga'

Translation:

'All at once to the west was overcast'

The sonnet, 'Mpande ye- Afrika' is devided into quatrains. The first quatrain presents the black people as happy and content. The black people are shown as oppressed by the white people in the next three lines. The last part has five lines. In this part, the black people liberate themselves using the white men's weapons.

The sonnets by Nondo and Dupute either have a binding line or a binding couplet. All thoughts are wrapped in these final lines to conclude each sonnet. After all the sweet words to Nomaluba in the sonnet, 'Luba elihle lami', Nondo writes:

'Nomaluba sithandw' awubuni

Woqhakaza kusasa lanini.'

Translation:

'Nomaluba, my love you do not wither

You will bloom tomorrow and forever'.

In the sonnet, 'Vuka Mlambatha', Dupute binds the sonnet by passing two general statements that contain everyday truths. He says:

'Lokh' imihlumela ikhuliswa mjuluko,

Lentandabuz' iyisikhwelo sendlala'.

Translation:

'As progress comes through sweat

So does hesitation become the ladder of hunger'.
The binding line in 'Ingoma Yesalukazi' is an apostrophe by the old woman who cries out:

'Kudla, we kudla, ngiyafa mina!'

Translation:

'Food, oh food, I am dying!'

The writer will now proceed to examine how sound, imagery and diction have been used by Nondo and Dupute to clearly bring out the themes of their sonnets.

\section{Stylistic Devices used in the sonnets}

Of the eight sonnets by Dupute in this study, four are about nature. Dupute effectively expresses the joy offered to us by nature. Man is viewed as having a special communion with nature. When the land is dry, man expects a bird to sing to the heavens so that the Heavens may open, sending down rain to soften the land. Dupute thus writes:

'Siza- kenyanga yezulu, tshay' icilongo,

Ngalelophimb' uwugwaz' umthombo phezulu

Lehle lichophelel' umhlab' uncibilike'.

Translation:

'Help rainmaker, low your trumphet,

Let your sweet voice pierce the Heavens

So that it may rain and the earth rejoices'

The sonnets 'Amabhawa', 'Ingoma Yesalukazi' and 'IEyidzi' show that Nondo's main concern is with the present times. Social problems of the present times are brought to the surface in a serious and sympathetic tone. With such concern and pity, he watches the world as it crumbles. Thus he writes:

'Safa ngotshwala, saphel' isizwwe

Lafa elihle kakhulu izwe'.

Translation:

'The nation has perished because of beer

Perished has the beloved country'.

Both poets have sonnets which are nostalgic about the glories of the past. In 'Ngo Bulawayo' Dupute writes:

'Amabizo az' angikhumbuz' amandulo

Ayethe nethe, kuze ngenyany'inamuhla'.

Translation:

'Their names remind me of the past

Their great comfort makes me despise the present'.

In 'Mpande ye-Afrika' Nondo says:

'Ubuhlez' uzinzil' umlom' unyunyuma

Uphuz' utshwala wesul' amagwebu

Abafazi lezingane bekubunganela 
Translation:

'You were comfortable and always had an oily mouth,

Drinking beer, wiping away froth

Surrounded by women and children'

Although both sonnets are nostalgic, Dupute's main message is that everything has an end whereas Nondo stresses that the oppressed are their own liberators.

As if to promote the Italian tradition of having sonnets, mainly, in respect of poems on courtly love, both poets have sonnets addressed to their beloved ones. Dupute calls his beloved ' Nomazilo' and Nondo names her 'Nomaluba'. The love theme is musically brought out by both poets.

Since its invention, the sonnet, like all other lyric poetry, has not lost its singing line. These musical words thus deserve to be read aloud. Burton [4] says:

'sounds far more than sight gives it its form'

Sounds appeal to the ear. It stirs some emotions and it reveals the mood of the poem. Words should, therefore, be arranged in such a way that the cadence of each line is not upset or disturbed. The sequence of sounds and words should have a rhythmic flow. This rhythmic flow causes the reader to smoothly modulate his voice, thus making the sonnet lines emotive and memorable. Studies by Cope [10] show that the musicality of poetry is achieved through repetition in various guises. Cope cites metre, alliteration, assonance and parallelism as the various guises of repetition. Ndebele/ Zulu, however, mainly achieve rhythm through alliteration, assonance and parallelism. Alliteration and assonance are inherent in the Ndebele/ Zulu concordial system where a set of concords are controlled by the noun class prefix. In the sonnet 'Inkanku' Dupute writes:

'Lehle lichophelel' umhlab' uncibilike

Phans' amathonga awathol' amanz' okuthoba'

Translation:

'So that it rains and gladdens the earth

And the dead, underground, receives soothing waters'.

He alliteration concords 'I' and 'a' give the lines a smooth rhythmic flow. The ear is kept in constant excitement and the pleasure and the coolness that is found if rain falls is expressed in and emphasized by the repetition of the ' $c$ ' and the 'the' sound. In the sonnet, 'Lub' elihle lami', Nondo writes:

'Izulu elina kucec' izwe

Uvukauvunele umhlaba

Zidle zijabule zonk' izizwe
Translation:

'The rain that falls and beautifies the earth

The awakened earth is dressed in beauty

All the nations eat and become merry'

The ' $v$ ' sounds, he ' $z$ ' sounds and the 'I' sounds are interwoven to convey the sense of pleasure and satisfaction brought by the falling rain. The sense that is being conveyed is reinforced by the ' $\mathrm{I}$ ' and the 'u' sounds.

Parallelism as a form of repetition features in the sonnets studied. There is parallelism by initial or final linking. According to Cope [10] and Nondo [27] a word or 'cognate' words are repeated at the beginning or end of successive lines. Studies by Cope show that parallelism by linking advances the idea discussed in the particular poem. In parallelism, descriptions are also piled for emphasis and beautiful sound effect. In the sonnet 'Ingoma Yesalukazi' Nondo writes:

'Ngilala ngamanzi ngifetezela,

Ngilala ngigoqene ngimafindofindo

Ngilala ngizitshila njengetshongololo

Translation:

'I sleep on water, turning up and down

I sleep twisting myself into many knots

In sleep, I twist myself like a milipede'

The old woman's plight is exposed in songlike fashion. The word 'ngilala' is repeated musically in three successive lines. For further emphasis, Nondo uses the word 'sengiswele', initially, in two successive lines of this sonnet. In the sonnet 'Lapha Ngicabanga' Nondo uses both the initial and the final linking. He writes:

'Lab' ukufa okubabizileyo,

Labo bonk' abangitshiyileyo,

Lab' amalib' abafihlileyo'

Translation:

'Those who have been called by death,

All those who have left me,

Those hidden in the bellies of graves'

'Labo' is the initial link and the final link is 'leyo'. Using words in this way facilitates retention and recitation. Both poets use noun-verb parallelism for emphasis. Nondo uses this type of parallelism within one line.

'Wangidanisa ngenzeni Danisile?'

Translation:

'You disappoint me, what have I done Danisile?'

Dupute spreads noun-verb parallelism over two lines:

'Lezondaw' elizibiza ngoTshabalala

Elizweni loluj’ olwatshabalalayo 
Translation:

'Those places you call Tshabalala

In the country of honey that has disappeared

There are instances where an idea is repeated in different words. This is called perfect parallelism. In the sonnets, 'Ngivumele Nomazilo', Dupute uses perfect parallelism to express his love, commitment and contentment. To emphasize the sweetness of Nomazilo's voice Dupute writes:

'Ilizwe lakho lingu Nomaju

LinguMnandis' endlebeni zami

Translation:

'Your voice is Honey

It is sweet to my ears

A sonnet does not only appeal to the sense of hearing, it also appeals to other senses. This is achieved through the use of imagery. The use of images evokes the reader's imagination, thoughts and emotions. It also creates vivid pictures in the reader's mind. Images are also used in sonnets to compress thought into the few sonnet lines. To create images, metaphors and similes are used. The reader is, thus, required to use his imaginative skills to make sense of the image before him. He considers all he semantic features brought out by a particular word and selects only the relevant and applicable features. Feature is relevant and applicable when it supports the idea discussed. When asking for artistic rebirths, Dupute writes:

'Phapham' uphekuze njengenyosi, nansiya...

Engiyibon' isuk' embalin' ensomi,

Ithi venenene, ithi ne kweliphuzi

Translation:

'Get up and fly about like a bee...,

I saw it rising off from a dark purple flower,

Flying swiftly and landing on a yellow one'

The bee is, in this case, admired for being ever busy. The line has nothing to do with the bee's painful stings or its sweet honey. The busy-bee characteristic is thus selected as the relevant semantic feature. In the sonnet, 'Ingoma Yesalukazi', Nondo writes:

'Ngilala ngizitshila njengetshongololo'

Translation:

'In sleep I twist myself like a millipede'

The old woman, in her sleep, is likened to a millipede. If poked, the millipede twists itself vigorously so as to bring itself to its normal position. The old woman twists herself in her sleep the whole night. This is, probably, used by the poet to indicate that the old woman no longer has any peaceful sleep.

Dupute likens the factory smoke to a snake, the mamba.

'Laleyontuthu ethunq' emafakithali

Iphum' itshilan' okwemamb' izw' amanxeba'
Translation:

'That factory smoke that issues

Uncoiling itself like a wounded mamba'

Naturally, a snake will uncoil itself as it comes out of a hole. Here, the uncoiling is intensified because it is done by a wounded snake. The reader clearly imagines a bi snake, painfully uncoiling itself as it emerges from a hole.

Nondo brings out images through use of metaphors. He says:
'Intamo bona ngeyentshe
Kant' izol' ibingeyethokazi'

Translation:

'See the neck is an ostrich's

Yet yesterday it was a heifer's'

During Danisile's healthy days, her neck was fresh and full of life and could be likened to the heifer's fresh and soft neck. Now Danisile's neck is sarcastically likened to the ostrich's long and skinny neck. The metaphor emphasizes Danisile's emaciated and helpless state. The effects of AIDS on an individual are identified in this sonnet. These are a heavy cough or tuberculosis, diarrhoea and loss of weight. The poet does not state these in plain words. The effects are metaphorically stated as follows:

'Umzimb' uzacile waluluthi lomchilo

Usifuba siyabhonga ngesenkuzi,

Uthumbu liyavuza yisifula samanzi

Translation:

'You are as thin as whip's handle,

Your chest bellows, it is a bull's,

Your stomach flows, it is a flowing rivulet'.

Danisile's body has degenerated o an irreversible state. Her thin state, extreme hoarse voice and continuous diarrhoea are brought out in a way which makes it obvious that Danisile will eventually die.

In the sonnet 'Ingoma Yesalukazi', the old woman's intestines continuously make noise, 'ngamachacho'. A trumpet is loved for its sweet music, but this time the music is not sweet. It is a sad tune sung by empty bowels.

According to Richmond [21]:

'Occasionally the main thought in sonnet may be couched in the form of imagery.'

Nondo does achieve this in the sonnet 'Lub' elihle lami.' Nomaluba is compared to fire, snow and rain which have attractive and bad features. Although the snow is attractive to the eye, it is extremely cold. The fire that warms us in winter can be very destructive. When rain falls, the earth awakens, is rich 
and green. Flowers bloom and all the earth's inhabitants get enough to eat. However, all the inhabitants are afraid of thunder and lightning. It is not so with Nomaluba. Nomaluba has he good side only. She is warm, fresh and she blooms forever. She is an everlasting source of life and pleasantness. Nondo writes:

'Wena kudla kobumina bami,

Ungumthomb' ogobhoz' ubumnandi

Nomaluba sithandwa awubuni

Woqhakaza kusasa lanini.'

Translation:

'You food of my soul

You are a well that springs sweetness

Nomaluba, my love, you do not wither

You will bloom forever"

Where imagery has been used sparingly, diction has been used in an imaginative way to create he needed impression of richness. Words are used to reveal clear pictures in the reader's mind. When describing the flying bird in 'Inyonyana Yamanzi', Dupute uses words 'intengezela' and 'idilingana' to show the different ways of flying displayed by the bird. The bird flies aimlessly over the dam but concentrates on one spot after it has spotted its target, thus getting ready to attack. To express the powerlessness of Mthwakazi men, Dupute uses the word 'bhabhalala'. The word gives a picture of a weak and powerless man, lying flat on his stomach.

In the sonnet 'IEyidzi', Nondo writes:

'Ngokugqibela ngakusasa sithandwa

Sikhukhuze yakuqeda iEyidzi'

Translation:

'Tomorrow I'll bury you my love

AIDS has gnawed you to the bone.'

The word, 'sikhukhuze', is used effectively to show that nothing is left of Danisile. A picture of a bone which has been scrapped of all the meat comes into the reader's mind. The word, 'gqibela', is not normally used when referring to people. The word is used because Danisile's immoral actions have brought embarrassment to her lover. Danisile's lover will thus bury Danisile and forget her soon after.

In the sonnet 'Mpande ye-Afrika', words are richly used to evoke the reader's emotions and imaginations. 'Mpande' is metaphorically used to tell the black man that Africa belongs to him. The phrase 'uzinzil' umlom' unyunyuma', shows how happy and content the traditional black man was. The black man had meat, beer and women in abundance.

The poet is very emphatic when he uses a succession of passive verbs, 'wancitshiswa', and wabhensiswa', 'wagotshiswa. The black men, as subjects, are being forcefully acted upon. However, time comes for black men to gain insight, to observe intensively and to graduate in thought.

'Wathungula, wabhekisisa, wathwasa'.

Translation:

'You opened eyes, observed and graduated'

Finally, he black man forcefully takes the white man's weapons and uses these weapons to liberate himself. Nondo, however, coins the verb 'khonta' to show that the black man's weapon has always been a spear.

Apt names that suit the sense and the tone of the sonnet are coined by both poets. Danisile lives up to her name. She is attacked by AIDS because of her immoral ways. Nomaluba is just like a flower. She is an antidote for all the unpleasantness and unhappiness in her lover's life. She is, indeed, a special flower, for she blooms forever. To appeal swiftly and commandingly to the reader's mind, Dupute coins romantic verbs and nouns when singing praises to his beloved Nomazilo. Dupute uses these nouns; 'Ntandose', Mbukwase', 'Nomaju', 'Mnandisi', 'Maqhwa' and 'Buhlalu'. The formative '-se' and he abbreviated noun 'no-" are feminine formations. Therefore, when Dupute calls his beloved 'Nomaju', he means that Nomazilo is the mother sweetness.

Some of the coined words are onomatopoetic. Appropriate and suggestive sounds are revealed as these words are read aloud. This makes the reader aware of the action that is taking place to the extent that, the described sounds, for a moment, ring in the reader's ears. Dupute writes f 'ukukwitiza', 'ukuswilitswiliza' and 'ukutshiloza' when he is describing the singing of the birds. He also uses 'ukuklwebuka' and 'oklabalayo' to describe the noise made by the whip and shouting people respectively.

Nondo uses words with doubled stem to clearly show the state of a particular object. The word 'bezibutofotofo' is used to describe Danisile's cheeks before she is infected with the disease AIDS. Her cheeks were fresh and as soft as wool. The word 'ngimafindofindo' is used to describe the old woman in her sleep. She sleeps huddled up into many knots.

Idiophones are common in the sonnets studied. They are used to capture, precisely, the actions and the movements expressed. Instead of explaining in many lines how and where the birds are travelling to, Dupute writes:

‘Mbo kanyekany’ empumalanga

Translation:

'All at once the east was overcast' 
The idiophones 'qabha', 'yaphaca' and 'congco' are used by Dupute to describe actions of birds. Nondo, too, uses ideophones to describe the manner and state of things. He is thirsty for beer and he writes:

$$
\text { 'Umphimbo wam' uthe qha' }
$$

Translation:

$$
\text { 'My throat is very dry' }
$$

To describe the attractively white but cold snow, Nondo writes:

$$
\begin{aligned}
& \text { 'Ingqoqwan' ethe nke ekhangayo } \\
& \text { Iqanda mo iqed' amaluba' }
\end{aligned}
$$

Translation:

'The white and attractive frost

Is icy cold and destroys the flowers'

Some ideophones are trebled for more emphasis. Nondo laments the black man's lost culture and lost self. He raises his voice in anger and says:

'Ubuwena bathi du du du'

Translation:

'Your self- esteem was totally destroyed'

The black man fights and regains his dignity as a man. Oppression becomes a thing of the past. Happily and proudly Nondo says:

'Ubuwena nampu, ubugqili du du du'

Translation:

''Here is your self- esteem, slavery is over'

The ideophones are onomatopoeic. They, therefore, give the sonnet the needed song-like characteristics. Euphemism has been used in some sonnets to show some respect. The old woman in 'Ingoma Yesalukazi', is dying of starvation. She has nothing to eat. To reveal this pitiable and unpleasant state the old woman says:

'Kuzinsuku ngingakwazi mina

Lokuph' elaphansi lomquba

Translation:

'It's many days since I have known

To give the ground some manure'

Rhetoric questions are used effectively to reveal internal worry and unsettledness. Dupute is worried because the homestead of the bull frog is in our drinking water. The croaking of the bullfrog leaves Dupute wondering whether the bullfrog is coughing or vomiting. Dupute thus asks:

'Yibuxokoxo kuyakhwehlelwa yini?

Ngithi kuyaxokozelwa yikuhlanza na?
Translation:

'There is loud croaking, are you coughing?

I say you are noisy, are you vomiting?

In the sonnet, 'IEyidzi', Danisile is in a helpless situation. She is also accused of immorality. Soul searching questions are thus asked by Danisile's lover;

\section{'Danisile sithandwa ukwenzeleni?}

Ukwenzeleni pho Danisile wami?

Translation:

'Danisile, my love, why did you do it?

Why did you do it then my Danisile

Finally, as the reader's voice moves up and down, the division between song and speech becomes subtle and pleasant to the ear. Vowels are elided. Elision of the final vowel becomes compulsory so as to produce the fast tempo needed when reading or singing sonnets. To further give the sonnet song-like characteristics, words are syncopated. As a result, the language becomes condensed and pregnant with meaning yet the sound becomes effective and appealing. In a musical way, Nondo writes:

'Usifuba siyabhonga ngesenkunzi

Uthumbu liyavuza yisifula samanzi’

Translation:

'Your chest bellows, it is a bull's

Your stomach flows, it is a flowing rivulet

The meanings of the words are extended. Most of the words get their meanings from the context. This stimulates and delights the reader's imagination, making the reader appreciate and understand the themes of the sonnets. It is, therefore, essential for the reader to note that all these features discussed above demand that sonnets be studied if they are to be appreciated.

\section{SUMMARY AND CONCLUSIONS}

The study shows that the sonnet forms have been borrowed from the western world by African writers, in general, and Zimbabwean writers, in particular, without much change. All the sonnets studied have fourteen lines. They all have a volta or change of thought somewhere in the fourteen lines and they are concluded with a binding line or a binding couplet. Sound, diction and imagery are effectively used to maintain the sonority of sonnets. Although the Petrarchan, Spenserian, Shakespearean and Milton rhyme schemes have not been, possibly used in Ndebele concords enrich the musical quality of Ndebele sonnets.

However, the range of view of this study is very limited as only the works of two Ndebele poets have been studied. Published Ndebele poetry anthologies show that there are many Ndebele poets today. The features examined in this study, probably, do not apply to sonnets written by other Ndebele poets. 
More detailed studies on sonnets need to be done so as to prove whether there are variations in the Ndebele sonnets which have escaped the present writer.

\section{APPENDICES}

\section{J.N.T DUPUTE}

IKHWIBI Mbo kanyekany’ empumalanga

Imisindo yaphikisana

Ukuklwebuka kwemicholo,

Imiphimb' eklabalalayo-

Kwanyikinyeka wonk' umhlaba,

Zasabelana zonk' impumalanga

yaqhuma;

Lduma laph' okungelafu,

Lez' ithunzi lacitshilanga.

Mbo kanyekany' entshonalanga-

Ingxubangxobe yemisindo -

Laduma lay' eningizimu

Lajika kaqond' ubuNondo

Sezw' ikhwibi selikude le- e!

NGIVUMELE NOMAZILO Ngivumele Nomazilo

Ngikubize ngawothando,

Ungu Ntandose womoya wami,

UnguMbukwase wamehlo ami,

Ilizwi lakho linguNomaju,

LinguMnandis' endlebeni zami

Uma lisithi, 'Ngiyakuthanda,'

Kujuluka wonk' umzimba wami

Uma lezondeb' eziikuwe

Zimomozel' isimo sothando,

ZinguNombali wamahlabathi

Obuhle bakhe lobukaMaqhwa

OnguBuhlal' ongaphandla ngaye-

Kungidibanis' ingqondo zami.

WOZA FRESH Woza, Fresh, wena mbong' efihlakeleyo

Yiza, uzw' imizwel' engifikelayo

Ngokungiqinisa kwakh' uthi,

'Phambili!'

Namhla ngibuk' imvelo ngatsha lugqozi

Lungisusa phansi ngiqong' emafini,

Ngibone konke kuphenduk' umbukwane.

Ngidakwa yikukhahlela komqhakazo, Ungibangela amatekenya, yelele

Sengibheda ngingelon' uhlanya;

Nxa ngisizw' ukukwitiza kwezinyoni,

Lokuwohloka kwamanz'

ezimpophoma,

Kungiguqul' umhambuma

wezingqondo,

Ngithi ngibona, sengikwelamathongo,

Engibond' emphandeni wobumbongi
INYONYANA YAMANZI Intengezela phezu kwamanz' edamu

Ihloz' isithunzana phans' emanzini Okwesikhatshana yendlala amaphiko, Wen' owabon' uve luntant' emoyeni Iyasuk' iwathi qapha-qapha-qapha, Ihlombe lizwakale likhuz' umoya Kunjal' iphikelel' itswilitswiliza, Kwaba angath' amanzi edam' alalele; Athulis' amaz' ukuwakazela,

Kunconyw' isimanga senyon' ihayiya,

Yehlise ngokudal' uukuphuthuma, Emanzini yaphaca! Phezulu njalo! Idilingan' emoyeni itsho ngengila Lize lithi gqwambi ngoluthi kwabonina.

INKANKU Thethela nkanku yezulu, tshiloza ngizwe; Khal' uphezu kweDombobhabi, qede wehle,

Ufik' uthi congco phezul' esiqongweni

Somgan' obuk' idumba lam' entshonalanga,

Khona ngolithola kahl' icilongo lakho Tshay' uveve lwakho phezul' iZulu lizwe.

Ukuth' umhlab' uyaklewuka ngembalela,

Kudilik' imisebe engahloniphi mthunzi,

Iphehl' ijul phansi njengemvukuzane. Iyothikaz' izithutha ziphumule.

Siza-ke, nyanga yezulu, tshay' icilongo,

Ngalelophimb' uwugwaz' umthombo phezulu,

Lehle lichophelel' umhlab' uncibilike,

Phans' amathonga awathol' amanz' okuthoba

NGITSHELE DLAMEDLU Ngitshele, dlamedlu, ngibuza wen' omdala

Ngiyesab' ukubuza abantwana, ngingeke;

Ngiyasola sengathi bazophaphalaza.

Ngizw' ubutsw-r-r, tswr-r, lobuxokoxoko

Phakath' enxulumeni yakho, nsizw' endala.

Yibuxokoxoko kuyakhwehlelwa yini? Pho kuke kukhwehlelwe sakuphikisana;

Son' isikhwehlela lisibek' emanzini. Ngitshela, dlamedlu, khuluma wen' omdala;

Ngithi kuyaxokokozelwa yikuhlanza na? 
Lidle kudla bani lahlanza

kanyekanye?

Wona amahlanz liwabek' emanzini!

Sinath' amahlanzo lezikhwehlela!

Kumbe yikubhodla na? Ngitshele,

dlamedlu.

VUKA MLAMBATHA Vuka mlambatha wakwami, yaluyaluza

Njengembong' engazibeki phansi izinqe,

Evuka ngovivi lwezinyoni zokusa

Ihambel' izimbal' ehlobo zither qhibu,

Zihlobis' umhlab' ohlamba ngemvula yehlobo

Phapham' upheuze njengenyosi, nansiya....

Engiyibon' isuk' embalin' ensomi, Ithi venenene, ithi ne kweliphuzi.

Nansi kwethe cwebe, nansiya kwethe klubhukwangath' aykholiswa mbali yambala munye.

Zula- ke khozo kwezifisa zami, jija Phikelel' ungalambathi msipha wami, Lokh' imihlumela ikhukiswa mjuluko,

Lentandabuz' iyisikhwelo sendlala.

NGOBULAWAYO Lezondaw' elizibuza ngo

Tshabalala,

Elizweni loluj' alwatshabalalayo,

Amabizo az' angikhumbuz' amandulo

Ayethe nethe, kuze ngenyany' inamuhla

Kanti lalezozindawo oNsukamini,

OMbizo labo Magwegwe labo

Mgandana,

Amagama az' angiqubul' umunyu

Uma amanyanda kaMthwakaz' owayeqhotsha,

Esabhabhalala aguquk' izigqili;

Laleyontuth' ethunq' emafakithali,

Iphum' itshilan' okwemamb' izw' amanxeba,

Ingikhumbuz' iNkos' itshis' uBulawayo,

Abaafo bathol' intuth' ising eZulwini

Itshel' izul' ukuwa kwelunda lesizwe.

S. J NONDO AMABHAWA Umphimbo wam' uthe qha,

Ngomile, ngilebhabhalazi,

Izolo bengiseMathonis' ebhawa,

Ngibuthela njengamanzi.

Amabhawa sechith' imizi,

Kabizi madoda wodwa,

Thina besinatha labafazi,
Bengahlezi bona bodwa bebephahlwe ngamadoda

Emabhawa akuhlonitshwa,

Omamazala badla labakhwenyana.

Abafanyana bagon' onokabantwana.

Safa ngotshwala, saphel' isizwe,

Laf' elihle kakhul' izwe.

INGOMA YESALUKAZI Ngingugogomathambo, ngimbambozodwa

Yindlala bobaba, angilakudlaa

Ngilala ngigoqene ngimafindofindo,

Ngilala ngizitshila njengetshongololo.

Ngingaphila ngani ngingadli lutho?

Izihlathi zami sezawela phakathi.

Sengiswele ngittsho law' umlaza,

Sengiswele son' esesikuba,

Amathumba ngamachach' esiswini

Ngoba kalalutho ngaphakathi

Kuzinsuku ngingakwazi mina

Lokuph' elaphansi lomquba

Kudla, we kudla, ngiyafa mina!

LAPHA NGICABANGA Lapha ngicabang' abangane bami

Abalel' emathunen' athuleyo

Lapha ngikhumbul' izinini zami

Zona lez' ezingitshiyileyo.

Lapha ngikhumbula ngabantu bonke

Engake ngajabula lab' impela,

Esake sahleka njalo sonke,

Sihlek' inhliziyo zibekezela,

Ngiyabakhalel' abafileyo,

Lab' ukuf' olibabileyo,

Labo bonke abangitshiyileyo.

Lab' amalib' abafihlileyo

Abant' esasihlala sonke,

Sijabula sonk' insuku zonke.

MPANDE YE- AFRIKA Mpande ye- Afrika, sigogo sikaNsundu,

Ubuhlez' uzinzil' umlom' unyunyuma,

Uphuz' utshwala wesul' amagwebu,

Abafazi lezingane bekubunganela;

Kwafik' isikhumba sikaMhlophe,

Wancitshiswa wabhensiswa wagotshiswa,

Umkhonto lebhetshu lehlwayi walahla,

Umkhonto lebhetshu lehlwayi walahla

Ubuwena bathi du du du;

Wathugulula wabhekisisa wathwasa, Wayithabath' incwadi kaMlungu.

Wayiphenya wayihlafuna wayiginya; Wazihluthul' izikhali zika Mhlophe,

Wazilola wakhonta ngazo,

Ubuwena nampu, ubugqili du du du. 
IEYIDZI

Bhek' umlilo wamehl' akho
Qhithile kwasal' amalahle.
Kanti bezibufotofoto,
Intamo bona ngeyentshe
Kant' izol' ibingeyethokazi.
Wangidanisa wenzeni Danisile?
Umzimb' uzacile waluluthi lomchilo,
Usifuba siyabhonga ngesenkunzi,
Uthumbu liyavuza yisifula samanzi.
Ukwenzeleni pho Danisile wami?
Ngokugqibela ngakusasa sithandwa,
Sikhukhuze yakuqed' iEyidzi.

Ingqoqwan' ethe nke ekhangayo
Iqanda mo iqed' amaluba;
Umlil' ukudla kwabaqhuqhayo
Ubhebhetheka kutsh' izintaba;
Izulu elina kucec' izwe
Uvuke uvunule umhlaba,
Zidle zijabule zonk' izizwe,
Libanika lidal' ukwesaba;
Kodwa wena lub' elihle lami,
Uyafudumala kawuqandi,
Wena kudla kobumina bami
Ungumthomb' ogobhoz' ubumnandi.
Nomaluba sithandw' awubuni
Woqhakaza kusasa lanini.

\section{REFERENCES}

1. Simpson, A. (1962). Beckett and Behan, and a Theatre in Dublin. London, Routledge.

2. Alan, I. (ED). (1981). The MacMillan Encyclopaedia. McMillan London Ltd.

3. Ford, B. (Ed). (1957). The Pelican Guide to English Literature. From Blake to Byron. Penguin Books.

4. Burton, S. H. (1974). The Criticism of Poetry. Longman.

5. Killam, G. D. (Ed. (1973). African Writers on African Writing. Cox and Wyman Ltd.

6. Collin \& Style (Ed). (1986). Mambo Book of Zimbabwean Verse in English. Gweru: Mambo Press.
7. Thomson, J. A. K. (1951). Classical Influences on English Poetry. George Allen a Unwin Ltd.

8. Benton, W. (ED). (1971). The New Encyclopaedia Britannica. Vol 16, 18. Encyclopaedia Britannia Inc.

9. Nondo, S. J. (1992). Epic Poetry: Its Nature and Main Characteristics. Unpublished Paper, U. Z.

10. Cope, T. (Ed). (1968). Izibongo: Zulu Praise Poems. Oxford Clarendon Press.

11. Petro, P. (1982). Modern Satire. Mouton Publishers.

12. Wolfe, H. (1929). Notes on English Verse. Satire Hazell Watson and Viney Ltd.

13. Simpson, L. (1986). An Introduction to Poetry. St Martin's Press.

14. Halsey, W. D. (Ed). (1969). Collier's encyclopaedia. Vol 15. Cromwell- Collier Educational Corporation.

15. Hogart, M. (Ed). (1965). The Faber Book of Ballade. Cromwell- Collier Educational Corporation.

16. Mpofu, P. (Ed). (1973). Ugqozi Lwezimbongi. Mambo Press.

17. Jump, J. D. (Ed). (1974). The Critical Idiom. The Ode. Methuen Co Ltd.

18. Jones E. (Ed). (1973). African Literature Today. Africana Publishing Company.

19. Nye, R. (Ed). (1976). The Faber Book of Sonnets. Faber and Faber.

20. Crosland, T. W. H. (1971). The English Sonnet. London Martin Secker.

21. Richmond, K. W. (1967). The English Sonnet. Cox and Wyman Ltd.

22. Wells, S. (Ed). (1986). The Cambridge Companion to Shakespearean Studies. Cambridge University Press.

23. Hubler, E. (1952). The Sense of Shakespeare's sonnets. Greenwood Press Ltd.

24. Moody, H. L. B. (1968). Literary Appreciation.

25. Chatwin, D. (ED). (1978). Notes on the Poetry and Prose of John Keats. College of Carreers.

26. Rodway, A. (1982). The Craft of Criticism. Cambridge University Press.

27. Nondo, S. J. (1985). The Main Features of Ndebele/ Zulu Praise Poetry: It's Nature, Stylistic, Devices and Uses. Unpublished Paper, U. Z. 